S. N. Bobylev a), O. V. Kudryavtseva ${ }^{\text {a) }}$, Ye. Yu. Yakovleva a)

a) Lomonosov Moscow State University

\title{
REGIONAL PRIORITIES OF GREEN ECONOMY ${ }^{1}$
}

The article is dedicated to transforming the economy of Russian regions to a green economy, which is an essential factor for the sustainable development. This is important not only for Russia but the whole world because our country has the great natural capital and provides important environmental services that support the planet biosphere. Based on the analysis of economic, social and ecological statistical data and Human Development Index (HDI) we have shown that the development of Russian Federal Districts is very unbalanced and each Russian region has its own way to new economic model. For instance, it is necessary to increase the well-being in the North Caucasus Federal District, it is important to reach higher life expectancy at birth in the Siberian and the Far Eastern Districts. It is necessary to move from the «brown» economy

${ }^{1}$ (c) Bobylev S. N., Kudryavtseva O. V., Yakovleva Ye. Yu. Text. 2015. 
to a green one by using the human capital (building a knowledge economy), by applying Best Available Technologies (Techniques), by investing in efficiency of use of natural resources and by increasing energy efficiency. The transition to a green economy will help to achieve social equity and the development of human potential; it helps to move from the exploitation of non-renewable natural capital to renewable human capital. All these socio-economic measures should give decoupling effect, make risks lower, reduce the exploitation of natural capital, stop the environmental degradation and prevent the ecological crisis. Transition to the green economic model has to be accompanied by new economic development indicators, which take into account social and environmental factors.

Keywords: green economy, sustainable development, green growth, human development index (HDI), human capital, low-carbon economy, social equity, energy efficiency, best available technologies, decoupling.

\section{Basic features of new economy}

The evident need to develop and implement a new economic model for the world and in specific countries runs like a thread through the outcome document of the Rio +20 Conference, entitled "The Future We Want" and speeches by leaders of the participating countries. The new model proposed is that of the green economy. This term is supplemented by a long series of definitions of the new economy, which are already used in research work and international documents: the knowledge-based economy (an economy based on knowledge); the innovation economy; the science-intensive economy; the information economy; the socially-oriented economy; the postindustrial economy, information economy, happiness economics, etc. Regardless of the formal definition, the proposed transformation of the traditional economic model is based on: prioritizing of human potential/ capital, knowledge and information; deep structural and technological changes; and compliance with environmental constraints. We give a general definition of the new economy as the "sustainable economy" in the unity of all its economic, social and environmental aspects. Given the need for a transition to sustainability, it is obvious that the future of the economy must be green, based on knowledge, and on social and technological innovation, etc. The different definitions of the new economy all agree on its main outline. Basic features, which should be inherent in the new economy, include:

- Environmental sustainability, greening of the economy.

- Social orientation.

- Maximum structural and territorial coverage.

- Putting a higher value on natural goods.

- Emphasis on knowledge. risks).

- Reducing risks (including environmental

- Innovation.

- Energy efficiency/low-carbon economy.

- Sustainable consumption and production.

- New approaches to measuring progress.
In what follows we will consider these features by means of the global and Russian situation.

Growing environmental constraints have led to the recognition, in both theory and practice, that the world needs a new type of economic development, a way forward in the economy based on green principles. The outlines of what is needed are made clear in initiatives by the United Nations Environment Programme (UNEP) for the transition to a green economy and the green growth programmes of OECD countries (2008-2012) [1; 2 ; $3 ; 4 ; 5 ; 6]$.

The green economy is defined by UNEP as an economy, which improves the well-being of people and enables social justice while reducing environmental risks and environmental degradation. [6] The key features of such an economy are the efficient use of natural resources, preservation and increase of natural capital, reduction of pollution, low carbon emissions, preventing the loss of biodiversity and ecosystem services, and the growth of income and employment. The priority feature of growth in the green economy is a radical increase of energy efficiency. Hence, the broad currency, which has been obtained by the term "low-carbon economy".

The green economy is not a substitute for the concept of sustainable development. But it is increasingly recognized that the achievement of sustainability depends almost entirely on shaping the "right" kind of economy. In past decades, humanity has created new wealth on the basis of an anti-environmental "brown" economy.

The emergence of a new economic model worldwide and in specific countries is increasingly evident, and the global crisis has contributed to the search for paths to a green economy. Many nations are working on anti-crisis programmes, which include a major environmental component. Examples include the EU's $20: 20: 20$ plan (for improvement of energy efficiency and the share of renewable energy by $20 \%$ and reduction of greenhouse gas emissions by $20 \%$, all to be achieved before 2020), US programmes to reduce greenhouse 
Table 1

Main sustainable development indicators for Federal districts of Russia, 2013

\begin{tabular}{|l|c|c|c|c|c|c|c|c|}
\hline $\begin{array}{c}\text { Federal } \\
\text { districts }\end{array}$ & $\begin{array}{c}\text { Gross } \\
\text { regional } \\
\text { income (GRI) } \\
\text { per capita, } \\
\text { rubles }\end{array}$ & $\begin{array}{c}\text { Unemploy- } \\
\text { ment rate, } \\
\text { percent }\end{array}$ & $\begin{array}{c}\text { Emissions } \\
\text { of air } \\
\text { pollutants, } \\
\text { thousand } \\
\text { tons }\end{array}$ & $\begin{array}{c}\text { Fresh water } \\
\text { consumption } \\
\text { per capita } \\
\text { per years, } \\
\text { cubic meters }\end{array}$ & $\begin{array}{c}\text { Morbidity } \\
\text { rate, per } \\
\mathbf{1 0 0 0} \\
\text { people }\end{array}$ & $\begin{array}{c}\text { Deviation } \\
\text { of life } \\
\text { expectancy } \\
\text { from mean } \\
\text { value, years }\end{array}$ & $\begin{array}{c}\text { Infant } \\
\text { mortality } \\
\text { rate, per } \\
\mathbf{1 0 0 0} \\
\text { newborns }\end{array}$ & $\begin{array}{c}\text { Natural } \\
\text { population } \\
\text { growth, } \\
\text { per 1000 } \\
\text { people }\end{array}$ \\
\hline Central & 489708,3 & 3,3 & 1569,96 & 253,35 & 720,9 & 1,17 & 7,6 & $-2,3$ \\
\hline $\begin{array}{l}\text { North } \\
\text { western }\end{array}$ & 406026,2 & 4,3 & 2316,89 & 676,78 & 856,6 & 0,49 & 6,2 & $-1,2$ \\
\hline Southern & 253152,3 & 6,5 & 716,36 & 509,03 & 723,2 & 1 & 7,9 & $-0,6$ \\
\hline $\begin{array}{l}\text { North } \\
\text { Caucasus }\end{array}$ & 142102,8 & 13 & 141,28 & 647,23 & 687,1 & 3,19 & 12,2 & 9,2 \\
\hline Volga & 288054,8 & 4,9 & 2547,90 & 286,09 & 873,6 & $-0,7$ & 7,5 & $-0,6$ \\
\hline Ural & 626119,2 & 5,7 & 4569,27 & 290,09 & 834,4 & $-0,7$ & 7,4 & 2,7 \\
\hline Siberian & 287026,9 & 7,2 & 5815,77 & 378,28 & 869,1 & $-2,13$ & 8,5 & 1,5 \\
\hline $\begin{array}{l}\text { Far } \\
\text { Eastern }\end{array}$ & 450126,2 & 6,5 & 769,12 & 276,53 & 832,8 & $-2,95$ & 11 & 1,3 \\
\hline
\end{tabular}

Sources: estimated by authors, based on statistics in Federal State Statistics Service: http://www.gks.ru/ and [9].

gas emissions, etc. Countries of the G20 are allocating nearly $16 \%$ or USD 522 billion to green investments out of a total USD 3.3 trillion package of government measures to stimulate the economy. [7]

Along with environmental priorities, the concept of the green economy gives much attention to the issue of social justice. The essence of the problem is clearly highlighted in the title of the Global UNDP Human Development Report 2011: "Sustainability and Equity: A Better Future for All". [8] The issue of social justice has many aspects: equality within and between generations, between rich and poor countries, in the distribution of income within countries, etc. Inequalities in consumption are also very pronounced inside some countries, including Russia, where the income gap between rich and poor is widening (Table 1).

As Table 1 shows, the Urals Federal District is the leader in GRP per capita, in the Central and Far Eastern Districts this indicator is significantly lower. GRP per capita in the South and North Caucasus Districts is 2.5-4.4 times lower than in the Ural District. The highest unemployment rate is in the North Caucasus District, it is almost twice higher than in Siberian District (the second place). These economic indicators are consistent with one very important social indicator - infant mortality rate. In the North Caucasus District, the infant mortality rate is 1.5 times higher than in other regions.

Ecological problems influencing the people and the environment include emissions of air pollutants. The Siberian and the Ural Districts are the regions with the highest levels of emissions. In almost all Russian Districts, more than a half of the urban population lives in cities with high and very high levels of air pollution (the largest share is in the Far Eastern District 62 \%). In the North Caucasus region, only $10 \%$ of the population lives in cities with low air quality, but, as we saw, it is accompanied by a low level of economic development. [9]

One of the most important components of life quality is health. According to morbidity rate about 80 \% of people in Russia, annually have newly diagnosed diseases. The highest level of this rate is in the Volga District (873.6 people per 1000) and the lowest (but not low) is in the North Caucasus District (687.1 people per 1000). According to average life expectancy, the most prosperous situation is in the North Caucasus District. Acute problems with health and longevity are in the Siberian and Far Eastern Districts. This problem is compounded by the negative natural population growth in the half of Russian Districts; the most acute situation is in the Central District (Table 1).

Compensating for natural resource use and overcoming their limitation and exhaustibility through the accumulation of knowledge is fundamental to the future economy and its sustainability. ${ }^{1}$ Humanity has to shift from development based on the use of natural resources to development based on the application of its most powerful renewable resource, which is knowledge. As T.Sakayya has said: "The only economic goods, which mankind will have in abundance and which will not have to be used sparingly, are human skills and knowledge." [11].

\footnotetext{
${ }^{1}$ The theme of the knowledge economy was central to the [10].
} 
Reduction of risks in the new economy is closely related to the process of accumulation of knowledge. These risks can be very diverse - from the financial risks, which led to the economic shocks in the world economy after 2008, to social risks associated with growth of the income gap, failure of the mechanism of social lift, etc. The principal feature of the new, green economy is a significant reduction of risks to the environment and its degradation. At present human knowledge of the laws of nature and environmental risks remain insufficient, and the global economic model remains environmentally maladjusted. The severe environmental crisis now being experienced by our planet is a result of these factors.

New nature-intensive megaprojects with unclear environmental outcomes should be viewed with extreme caution. The huge oil disaster in the Gulf of Mexico in 2010 showed the environmental risk of offshore projects, and future plans for Russian energy production on Sakhalin Island and in the Barents and Kara Seas should be considered in that light. Global climate change may affect the projected new energy production sites in various regions of the world, including the permafrost regions of Siberia and the Far East.

Adequate economic valuation of the environment in the process of economic decision-making is an important aspect of the new economy. There is a clear need to place a higher value on natural goods (resources and services) in economic theory and practice. [12] The world is increasingly aware of the limitations of equating natural capital with natural resources, and successful economic growth requires that other functions of natural capital should be recognized. Hence an attempt to take the economic significance of all the components of natural capital into account, in both theory and in practice, reviewing their ability to generate income and benefits, as befits any form of capital. In general terms, four functions of natural capital can be distinguished:

1) The resource function (providing resources for the production of goods and services).

2) Regulative environmental services (absorption of pollution and waste, regulation of climate and water regimes, etc.).

3) Functions associated with aesthetic, ethical, moral, cultural and historical aspects of man's relationship with nature ("spiritual" environmental services).

4) Ensuring that human beings and the environment remain in good health (this feature is still new to economics and, to a certain extent, it is a derivative of the first three functions of natural capital, but it can be treated separately in view of the priority of health for the development process).

One of the main reasons for negative environmental impact from economic activity is the hiddenness (latency) of many environmental problems: the traditional market simply does not see them. A modern economy cannot accurately gauge the benefits and damage that it produces for the economy and the environmental price of its operations, it cannot put environmental issues into figures and represent them in economic terms to government, business and society. Outstanding environmental and economic problems include: the absence of valuation of the majority of natural goods; underestimation of environmental damage; diffusion of benefits; inadequate reflection of the time factor (short-sightedness of the market); and public goods.

A critical problem for specific economic decision-making, preventing optimal functioning of the market, is undervaluation or lack of any valuation for many natural resources and services. There are no markets for many natural goods, and the harsh rule of any economy is: "What has no price, no economic evaluation, does not exist for the economy and is not taken into account in economic decision-making." If an attempt is made to include natural capital in the decision-making, it becomes apparent that only one of its functions that of resource provision - is in fact included in the market system, while the others (regulatory, cultural, aesthetic, etc.) are effectively outside the market. The theory says unequivocally: undervaluation or lack of any valuation entails that goods/resources are used and consumed in excessive amounts (over-used), which inevitably leads to their degradation and depletion.

A consequence of the failure of the modern economy to adequately value natural goods is the underestimation of environmental damage or, in the language of economics, of negative externalities. Many conservation measures would have been unnecessary if the exact external costs from the operation of polluting industries had been known, since a "polluter pays" principle could have imposed additional payments on businesses that pollute the environment.

The latent (hidden) nature of environmental problems is also manifest when benefits from the operation of many environment systems are underestimated or even ignored due to the diffusion (dispersion) of these benefits. The market economy cannot take account of the mechanisms of many positive natural effects. The economic benefits of ecosystems are often dispersed over large areas - the entire planet in many cases - and a 
huge share of these benefits are manifested and consumed far from the system that created them. For example, the existence of a local ecosystem such as a wetlands - of little evident value to the owner - proves extremely beneficial over large territories due to its function in preventing fires and floods, and treating water [13]. So the conservation of wetlands provides "off-market" values to various beneficiaries, who may be at a distance of tens, hundreds or thousands of miles from the actual wetland habitats. Russia experienced this to the full in recent years, when fires caused enormous economic damage. And wetlands have important economic benefits for the world community because they bind greenhouse gas emissions. Another example: if all the ecosystem functions of forests (water regulation, carbon sequestration, air purification, flood prevention, etc.) are taken into account, the value of wood in living trees is 3-5 greater than its value as timber.

The mechanisms of the Kyoto Protocol for preventing global climate change represent an important precedent for adequate measurement of the value of nature's benefits, both for economic theory and for practical action. By agreeing to establish a new global market for greenhouse gas emissions, the countries of the world agreed, in effect, to trade fresh air. Each ton of greenhouse gases now has its own specific price based on supply and demand and the cost of reducing the emission of these gases. It is highly important that the mechanism gives a valuation to the regulatory functions/ ecosystem services of forest and agricultural land in binding greenhouse gas emissions.

\section{Measurement of green economy}

How is progress toward a green economy - the rate of greening of sectors and activities - to be measured? The first step is to change the views of the vast majority of politicians, businessmen and scientists on the issue of development, which currently remain tied to such mottos as "economic growth is the key to progress," "growth first, and then the solution of environmental problems", etc. Such mottos had remained unchallenged until recently. In the existing economic stereotypes, economic growth is usually identified with increase of gross domestic product (GDP), the maximization of profits, cash flows and other financial indicators, while the quality of growth and its costs (environmental and social) are usually ignored. Use in the decision-making process of economic and financial measures that do not fully reflect the real economic, social, and ecological processes, is largely what led to the global crisis. The prime example of an indicator that fails the test of sus- tainability is $\mathrm{GDP}^{1}$ - the most classic and widely used economic indicator in the world. Until now, the vast majority of countries, including Russia, have measured their development success by the value of this indicator. But, GDP, which began to be applied at the beginning of the 1950s, is only suited as a measure of traditional industrial economies. By contrast, the growth of GDP in countries with large natural capital through expansion of their resource sector is of dubious value. The easiest way to achieve such growth is by over-exploitation of hydrocarbon and coal fields, forests, land, etc. In particular, Russia's favorable GDP before the crisis was largely based on the depletion of natural capital and shift of the Russian economy to a raw-materials export model.

The Rio +20 Conference criticised excessive reliance on GDP for assessing progress. The UN Statistics Commission has now developed new approaches to greening of the System of National Accounts, proposing new approaches to global environmental accounting, which cover the most important aspects of resource efficiency and environmental damage. [16]

Appropriate indicators are needed to carry out monitoring and judge whether movement towards a green economy is taking place or whether the "brown" economy is being perpetuated. Work in at least two directions is required: to develop sustainable development indicators and to achieve the effect known as "decoupling" (see Fig. 1, 2, 3) ${ }^{2}$.

We exclude the year 2009 because of the negative economic growth, but the whole tendency was taken in account in the index for 2010. Our estimates (Figures 1 and 2) show that there is "decoupling" effect in water consumption and air pollution. That means that the rates of growth in water consumption and air pollution were lower than the rate of DRP growth in all Russian Districts for 14 years (from 2000 till 2013).

Figure 3 shows that there is no decoupling effect in waste management till now. The amount of waste produced is growing faster than GRP in all Russian Districts. In 2013, there was some improvement in Russia as a whole, but in Central, Ural, Southern and North Caucasus Districts the situation became worse.

Another widespread aggregate indicator is the Human Development Index (HDI). Primarily it shows the social aspect of sustainable development. HDI is based on three indicators: life expectancy at birth, level of educational attainment

\footnotetext{
${ }^{1}$ For more detailed discussion of issues connected with the design of sustainable development indicators, see: [14], [15].

2 The metrics of decoupling see [17, pp. 111-113].
} 
and standard of living. The last one is measured as GDP per capita and is based on purchasing power parity (PPP).

The longevity (life expectancy at birth) essentially depends on the environmental situation. According to the estimates of medical profession- als, the contribution of environmental pollution in the mortality rate can reach up to $20 \%$.

Environmentally caused morbidity and mortality are relevant for many Russian regions with adverse environmental conditions. The increase of pollution and environmental degradation, imba-

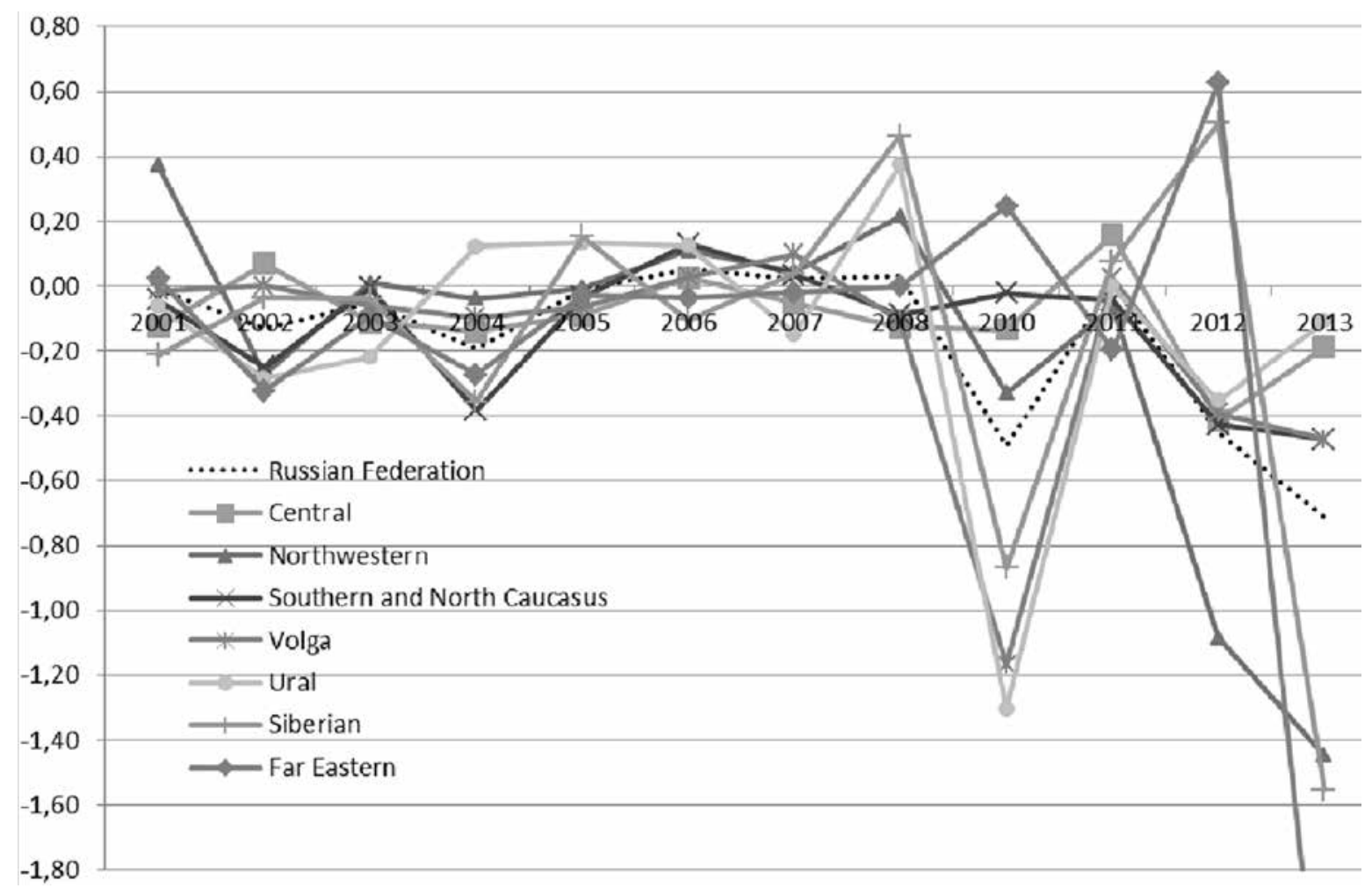

Fig. 1. Decupling index for fresh water consumption

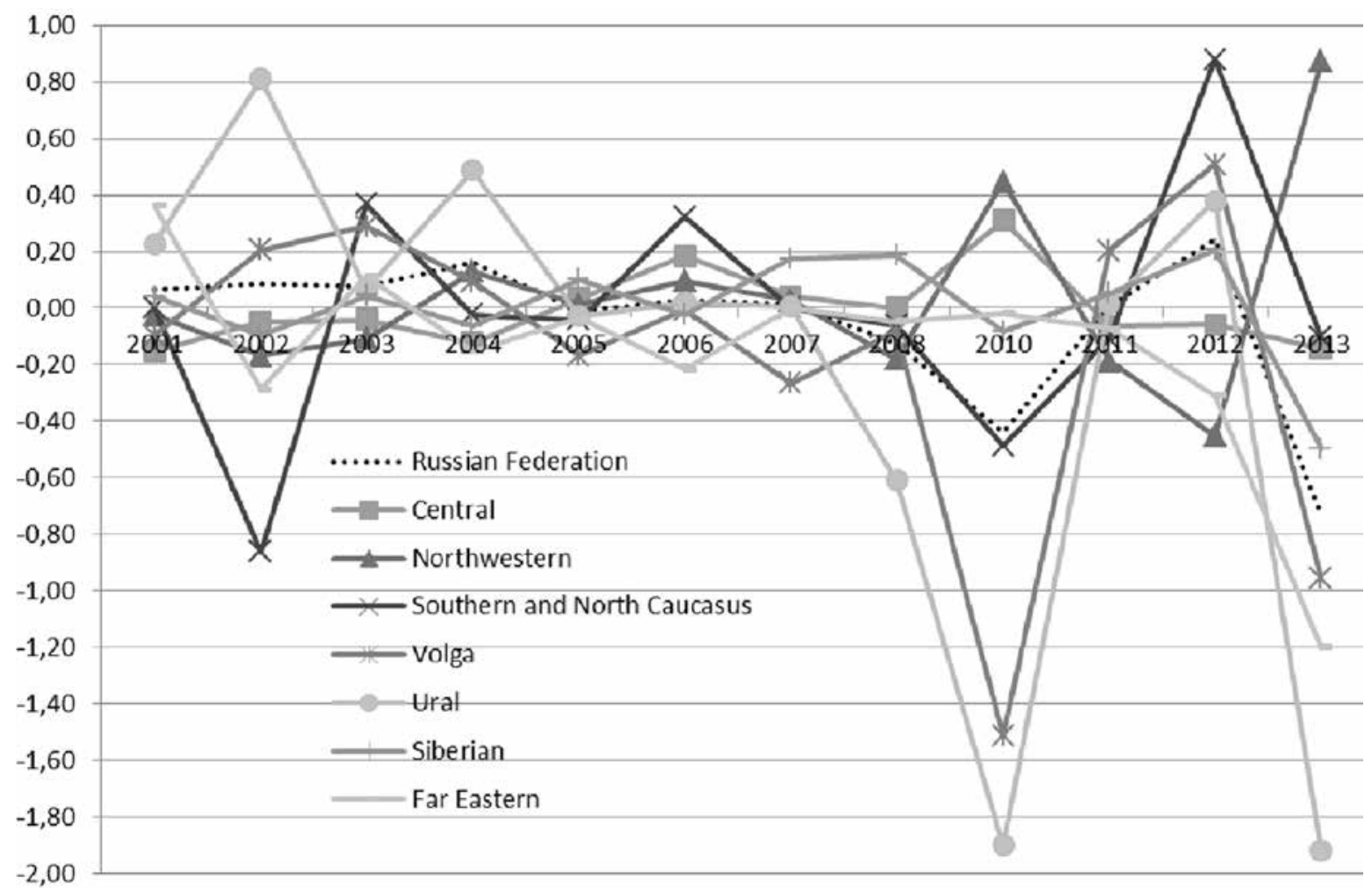

Fig. 2. Decupling index for air pollution 


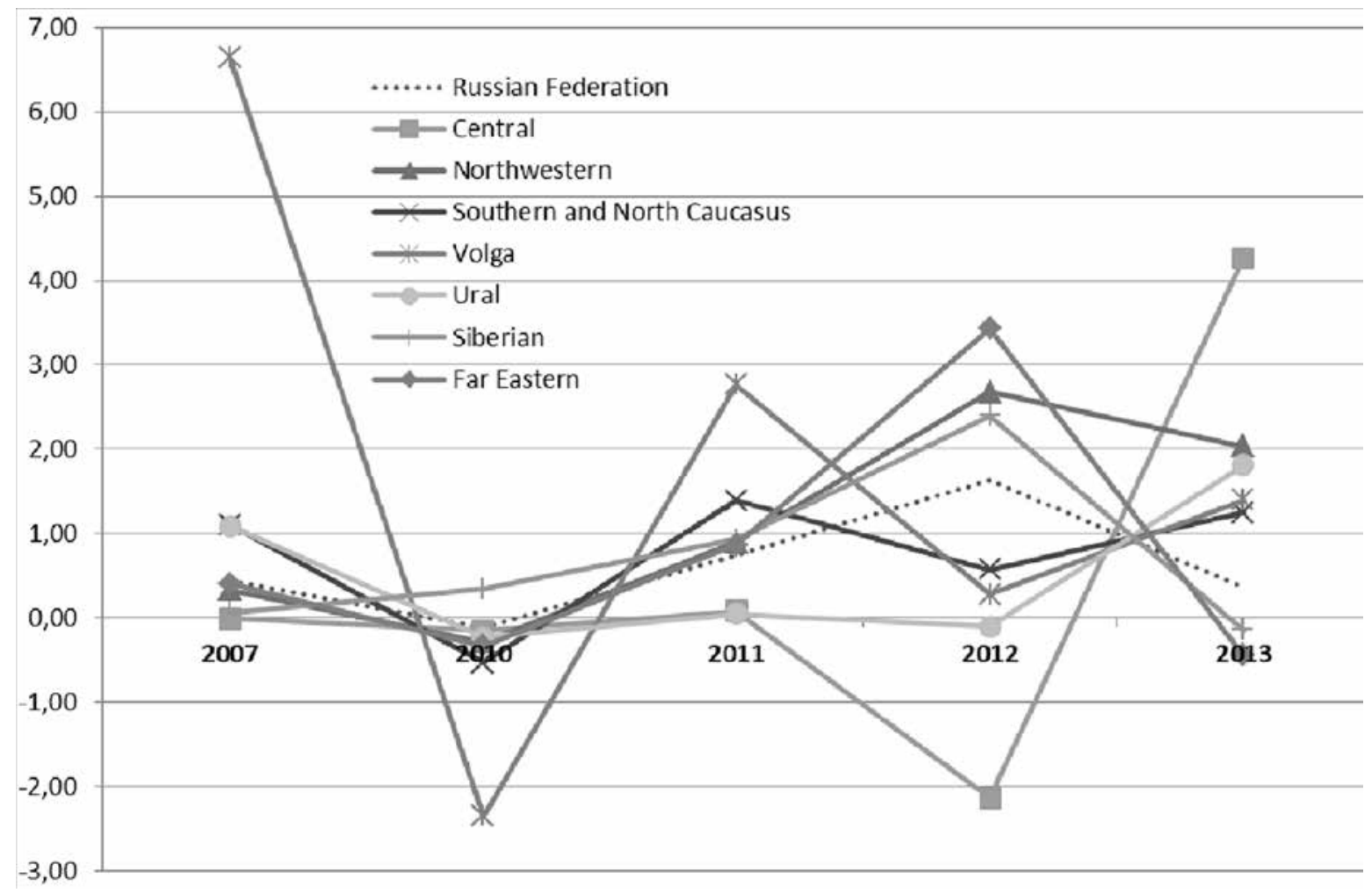

Fig. 3. Decupling index for waste production

Table 2

Ranking of Russian Federal Districts on HDI, 2013

\begin{tabular}{|l|c|c|c|c|c|}
\hline \multicolumn{1}{|c|}{ Federal Districts } & $\begin{array}{c}\text { Gross regional income } \\
(\mathbf{G R I}) \text { per capita, rubles }\end{array}$ & $\begin{array}{c}\text { Life expectancy } \\
\text { at birth, years }\end{array}$ & $\begin{array}{c}\text { Literacy rate, } \\
\text { percent }\end{array}$ & $\begin{array}{c}\text { Share of students in } \\
\text { the age 7-24, percent }\end{array}$ & HDI \\
\hline Central & 489708,3 & 71,93 & 99,81 & 0,77 & 0,85 \\
\hline Northwestern & 406026,2 & 71,25 & 99,79 & 0,76 & 0,83 \\
\hline Southern & 253152,3 & 71,76 & 99,62 & 0,73 & 0,80 \\
\hline North Caucasus & 142102,8 & 73,95 & 99,17 & 0,59 & 0,77 \\
\hline Volga & 288054,8 & 70,06 & 99,64 & 0,77 & 0,81 \\
\hline Ural & 626119,2 & 70,06 & 99,72 & 0,78 & 0,85 \\
\hline Siberian & 287026,9 & 68,63 & 99,62 & 0,76 & 0,80 \\
\hline Far Eastern & 450126,2 & 67,81 & 99,74 & 0,77 & 0,82 \\
\hline
\end{tabular}

Sources: estimated by authors, based on [17, p. 40-42].

lance of the biosphere are determined by the «raw» economic growth, which leads to a deterioration in human health and limits opportunities for further human development /capital. The economic costs for the health of the Russian population related to air and water pollution are not less than 4-6 \% of GDP. In some Russian regions environmentally caused health damage can reach $10 \%$ of GRP, especially in the Ural regions.

HDI is calculated annually since 1990 in the UN Development Programme (UNDP) and is included in the Human Development Report of the United Nations Development Programme. Now more than 100 countries are publishing these reports using the HDI.
In Table 2 you can find ranking of Russian Federal Districts on HDI. Components of the Index show the advantages and disadvantages of Russian federal districts in the field of human development [18].

As one can see the Ural District is ahead of the Central District in GRP per capita, but in the Central District the life expectancy at birth and the level of educational attainment are higher. As a result, the Central and Ural Districts have the same level of HDP (0.85). Despite the highest life expectancy at birth in the North Caucasus District, it has the lowest level of GRP per capita and the lowest level of educational attainment, and this 
resulted in the lowest level of HDP for the North Caucasus District (0.77).

An important issue is the territorial and structural-technological scale of the green economy. The green economy can only succeed if it is global. Greening in a limited area (in the developed countries, for example) cannot ultimately be successful without transformation of the world's major economies. Developed countries alone - for all the effectiveness of their own efforts to shift to a low carbon economy - will be unable to prevent destruction of the global climate system unless there is coordination with the largest emitters of greenhouse gases, which are China, India and Russia.

The issue of the structural and technological scope of the green economy is also controversial, and much confusion attaches to it at present. The green economy is often understood to refer only to green business, which covers the production of various types of pollution control equipment, utilization of secondary resources and waste, the provision of environmental services, etc. In this case, the green economy is a part of the "big" economy. But, clearly, peaceful co-existence of such a green economy with the natural-resource "brown" economy is hardly possible. The green transformation has to extend to the whole economy, and the greening process can only be effective in the long run if it includes the macro level. The issue of energy efficiency and the low-carbon principle are of central importance for the new economy.

The transition to a green economy will happen differently in different countries, because it depends on the specifics of the natural, human and physical capital of each country, its level of development, socio-economic priorities, and the level of environmental culture. The final document of the UN Conference in Rio de Janeiro, "The Future We Want" (2012), stresses that each country can choose the approach to transition to a green economy, which best suits its national plans, strategies and sustainable development priorities. A rigid set of rules is not desirable.

\section{Green economy and Russian policy}

The concept of the green economy is essentially new for Russia and is hardly ever used in official documents. However, national targets, which have been set for the next 10-20 years, largely correspond to the objectives of transition to such an economy. This is reflected in the general policy for the use of resources and protection of the environment in the future, and in legal and economic instruments, which are available. The main task of the Russian economy at the present stage, as reflected in the principle documents describ- ing the country's development trajectory in the medium and long term, and also in speeches by the Russian President and Prime Minister of the Russian Federation, are for movement away from raw material dependence. This is also the central objective in the green-economy concept. The task has a central place in main Government documents: the Concept for Russia's Long-Term Development (2008); the draft Strategy for LongTerm Development (the "Strategy 2020") (2012); Principles of State Policy in Environmental Development up to 2030, approved by the President of the Russian Federation (2012); etc. For example, although the latter document does not use the term green economy, the strategic goal of Government environmental policy up to 2030 is proclaimed as being: "the solution of socio-economic tasks, ensuring environmentally-oriented growth of the economy" ${ }^{1}$. In this context, the term "environmentally-oriented growth' largely coincides with the term green growth.

A key goal of the green economy is energy efficiency, and this is a particular priority for Russia. It is set out in the Energy Strategy of Russia up to 2030 (2010), the Presidential Decree "On improving energy and environmental efficiency" (2008) and the Law on Energy Efficiency (2009). Development priorities for green sectors of the economy have been reflected in existing longterm programmes for specific resources.

Russia can play a crucial role in the formation of the new global green economy. It can do so by virtue of its huge natural capital and ecosystem services, which contribute to the sustainability of the biosphere and provide economic benefits to all mankind. Russia's vast areas untouched by economic activity, its colossal forest and wetlands, freshwater, biodiversity potential - all of these make a major contribution to shaping the new global economy. As Dmitry Medvedev said at the Rio +20 Conference, Russia is an environmental donor to the world. The country must play a more active role in greening of the global economy, from which it can obtain economic benefit by "capitalizing" its status as an environmental donor. These opportunities are also discussed in the Concept for Russia's Long-Term Development (2008). In this regard, it is highly important for Russia to coordinate national efforts with those of international organizations, particularly in the framework of the WTO, which Russia joined in 2012, and to integrate the principles of inter-

\footnotetext{
${ }^{1}$ Public policy framework in the area of environmental development of Russia for the period up to 2030. Internet site of the President of Russia [site]. URL: http://news.kremlin.ru/ acts/15177 (accessed date: 20.10.2014).
} 
national agreements in the country's own legal framework and economic decision-making.

To achieve its environmental objectives, Russia must radically change the trend towards commodity exports, which has enormous inertia power currently. It is becoming increasingly clear, as confirmed by the economic crisis, that Russia's economic model based on the export of raw materials has exhausted itself. Environmental sustainability has become an important feature of the new model for the national economy. [11] "Unsustainable" aspects of Russia's current development trajectory are confirmed by: the exhaustion of natural capital as a factor of economic growth; structural shifts in the economy; the increasing relative share of natural-resource exploiting and polluting industries; the growth of environmental risks due to the high physical wear of equipment; high levels of environment intensity; dominance of natural resources in exports; environmental imbalance in investment policy, leading to an increase in disparities between natural-resource sectors and the processing, manufacturing and infrastructure sectors of the economy; impact of environmental pollution on human health; etc.

The development of unsustainable trends is largely due to the natural-resource-intensive restructuring of the economy in the 1990s towards raw-material and polluting sectors, and worsening of the "environmental quality" of plant and machinery, which was accompanied by the decline of resource-sparing and high-tech industries. The Russian President Vladimir Putin has described the result of these trends as "a large-scale de-industrialization”. [19] High energy prices, particularly the huge increase in prices for oil and raw materials in the 2000s, contributed to making the structure of the Russian economy more "heavy". Energy and metallurgy (ferrous and non-ferrous), which have the largest impact on the environment of any industrial sectors, currently account for more than half of Russian industry. The share of industries that have relatively little impact on the environment, notably machine-building, declined in the same period. The crisis exacerbated Russia's environmentally negative structural changes, since export-oriented raw material industries, survived best, helped by Government support. The Russian economy is becoming increasingly dependent on commodity exports.

Unfortunately, the new environmental and economic realities are not taken into sufficient account by documents on Russia's long-term economic development. For example, the generally constructive and ambitious Strategy 2020 (2012), developed for the Russian Government Federation by leading experts for the period up to 2020, takes much account of social factors, but has little to say about the environment. The strategy is also based on the traditional paradigm of GDP. The new economy should focus on qualitative rather than quantitative development. Instead of striving to increase production and consumption of natural resources, with increasing impact on the environment, Russia should make better use of the raw materials, which are already drawn into the economic cycle. Russia has huge potential for saving natural resources by means of modernization. The pursuit of quantitative indicators, whether of value (GDP, etc.) or volume (amounts of oil, gas, metals, etc.), is mistaken. Quantitative indicators should take second place to the social and environmental quality of growth.

In order to attain stability the future economy should have the following key features:

- Economic strategies / programmes / plans should include aspects expounded in UN and OECD documents on the green economy and growth, and on the low-carbon economy ${ }^{1}$.

- Acknowledgement of the importance of environmental living conditions of the population and maintaining decent environmental living conditions.

- Priority development of knowledge-intensive, high-tech manufacturing and infrastructure industries with minimal impact on the environment, typical of the knowledge economy.

- Reduced share of the raw materials sector in the economy.

- The radical increase in the efficiency of natural resource use and resource savings, enabling the major reduction of natural resource expenditure and pollution per unit of end-product (reduction of environmental intensity and pollution intensity).

- Less pollution of the environment.

Transition to sustainable development requires compensation of Russia's natural capital depletion by the growth of investment in human and physical (man-made) capital. Key steps include a drastic increase of investment in science, education, public health, innovative development, and the development of special funds (similar to the Fund for Future Generations), which are used in many countries around the world.

The most important goal of economic policy, supported by Government, business and society, should be a transition to sustainable development in the entirety of its economic, social and environmental components. The priority for

${ }^{1}$ See, for example $[1 ; 2 ; 3 ; 6]$. 
achievement of the green economy and the greening of economic policy can be summarized: Do not maximize levels of use of natural resources, since they are limited, and their rapid consumption leads to additional pressure on ecosystems, depletion of natural capital and environmental pollution. Existing, outdated and resource-intensive technologies also lead to over-consumption, the loss of natural resources and increased pollution. Technological modernization of the Russian economy and its structure could release 30-50 \% of all the natural resources, which are now used inefficiently and wasted while increasing the final results of production processes. Production levels and the territories used for development of energy resources and minerals, as well as areas used for farming, and rates of deforestation, etc., can be stabilized. As made clear by the Energy Strategy of the Russian Federation for the period up to 2030, almost half of the energy now consumed in Russia could be saved by the installation of fairly simple energy-saving technologies.

Investments are needed to improve the use of natural resources that are already being developed and to protect the environment through modernization of the economy, support for innovation, replacement of resource-intensive technologies by technologies that are resource-sparing and energy-efficient (best available technologies), deepening and diversification of raw material processing, etc. This will improve the well-being of the population, increase GDP by $2-3$ times at the present level of raw material extraction and use of natural capital, and reduce levels of pollution.

This is the high road to the creation in Russia of a new, green economy: by investing in resource-saving restructuring of the economy, radically changing the technology base and reducing environment intensity, the costs that are needed to counter the negative environmental effects of economic development can be minimized now and in the future.

The conditions for transition to a green economy, as formulated in the documents of international organizations, highlight the need to limit costs in sectors that deplete natural capital. $[1 ; 2 ; 3$; 6] Russia should not rush ahead in the near future with high-cost mega-projects to exploit new natural resources, particular energy resources, with unpredictable consequences for the environment and the human population (at offshore zones and the permafrost zone, where transport infrastructure is lacking, etc.). Such caution is justified not only by environmental considerations, but also by purely economic logic: swings and falls in world market prices for raw materials may cut off a significant part of the market for output from new fields with their infrastructure and pipelines by making them unprofitable, as is already happening to some extent in the gas market due to increased global production of shale gas. We must hold back from the rapid development of capital-intensive new fields. Growth in levels of final output can instead be achieved by enhanced recovery techniques, equipment upgrades and deeper processing of raw materials, including for export.

The priority of macroeconomic steps, which determine economic development, economic growth and well-being of the population, is evident to decision-makers in today's economy. But the environmental consequences of economic policy are receiving insufficient attention in Russia. In the transition to a green economy, measures of economic policy need to deliver environmental gains (or be at least environmentally neutral), achieving a "win-win" situation on economic and environmental fronts. This amounts to a "fusion" of macroeconomic and environmental policies. At the national level, examples of this fusion include: adjustment of fiscal policy (heavier taxation of resource use and pollution); reform and the reduction of subsidies that lead to degradation of natural resources and the environment; the introduction of new market instruments; transition to green public procurement; improvement of environmental standards and ensuring that they are applied; environmental insurance; the creation of new green jobs and associated re-training of employees from the "brown" economy. All of this can improve the competitiveness of the green economy. A classic example of the "win-win" approach would be radically improved energy efficiency (by $40 \%$ up to 2020), which can provide huge economic benefits as well as environmental dividends.

Environmental "rules of the game", set by Government for the economy, encourage private business to recognize and use genuine opportunities offered by the transition to a green economy in a number of key sectors, and to react to the reform of public policy and price signals by increasing financing and investment in greening of the economy.

Greening of public procurement could give a major boost to the green economy. Procurement accounts for a significant proportion of total government spending in both developed and developing countries, and sustainable public procurement techniques can generate high and long-term demand for green products and services, encouraging private and public companies to make longerterm investments in innovation, and manufacturers to carry out economies of scale, reducing their 
Depreciation of fixed assets, percent

\begin{tabular}{|l|c|c|c|c|c|}
\hline \multicolumn{1}{|c|}{ Federal Districts } & $\mathbf{2 0 0 9}$ & $\mathbf{2 0 1 0}$ & $\mathbf{2 0 1 1}$ & $\mathbf{2 0 1 2}$ & $\mathbf{2 0 1 3}$ \\
\hline Russian Federation & 45,3 & 47,1 & 47,9 & 47,7 & 48,2 \\
\hline Central & 40 & 43,8 & 44,9 & 44,4 & 45,6 \\
\hline Northwestern & 44,5 & 45,4 & 45,4 & 44,1 & 43,9 \\
\hline Southern & 44 & 44,6 & 45 & 45,3 & 42,6 \\
\hline North Caucasus & 43,7 & 44 & 44,5 & 44,8 & 44,8 \\
\hline Volga & 51,2 & 52,6 & 49,8 & 53,7 & 53,7 \\
\hline Ural & 52,1 & 52,8 & 56,3 & 53,4 & 55,1 \\
\hline Siberian & 45,2 & 45,8 & 46,5 & 46,5 & 47,5 \\
\hline Far Eastern & 40,6 & 42,2 & 43,5 & 45,5 & 45,1 \\
\hline
\end{tabular}

Sources: estimated by authors, based on statistics in Federal State Statistical Services: http://www.gks.ru.

costs. This in turn can contribute to the wider commercialization of green products and services, creating the conditions for sustainable consumption.

Payments for ecosystem services, which are being implemented in several countries can expand the market and raise the valuation of natural resources and services. An approach similar to that used in the Kyoto Protocol mechanisms should be extended to all kinds of natural resources and services, not just those that are already "in the market”. Payments for ecosystem services offer new development prospects for Russia, due to its huge natural capital.

As well as economic means of regulation, the Government should also make greater use of legal and institutional mechanisms in the field of natural resource use and conservation. Ensuring the execution and implementation in practice of Russia's extensive environmental legislation is particularly important for progress towards the green economy.

Innovation, science and technology development, information technology, new materials, products and technologies, etc., can reduce consumption of natural resources and the amount of pollution per unit of production and services by several times. Modernization through the renewal of fixed assets in the industry offers huge potential for transition to a green economy. Old equipment cannot make efficient use of natural resources and lead to the growth of pollution. As much as half of Russian industrial fixed assets are full depreciated and in need of replacement. Over the past five years, the depreciation of fixed assets in the Ural and Volga Districts had the highest level, and it was higher than $50 \%$ share of all fixed assets. In 2013, the «lowest» rate of the depreciation of fixed assets was in the Southern District but it accounts for $42.6 \%$. This means that even in this district fixed assets were crucially depreciated (Table 3). The aging of physical capital and the growth of environmental risks can have potential benefits, which should be exploited: 1) the possibility of significantly reducing natural resource use and pollution per unit of production by deployment of best-available technology; and 2) a technology "leap" that enables radical improvement in the use of natural capital.

The concept of best-available technology has already proven its high environmental and economic efficiency in the European Union. In Russia, the Ministry of Natural Resources has prepared a law for large-scale implementation of these technologies, which will serve as a new regulatory basis in environmental protection and help to put economic incentives in place. In 2014, the law «About making amendments to the Federal «Environmental Protection Act» and to some Russian legislative acts» was adopted by the State Duma and signed by the Russian President. These amendments should lead to radical technological shifts in the Russian economy towards the introduction of best available technologies.

Russia's accession to the WTO presents new challenges for the Russian economy. Despite the undoubted advantages of membership, there is a risk that it will strengthen the raw materials export model, which contradicts the goals of modernization and greening of the economy. Clearly, for the global market, and for multinational and foreign companies operating in Russia, the country's natural-resource industries are the prime attraction. This refers particularly to energy resources, which are highly competitive goods. It would be foolish to expect substantial foreign investments in hightech industries and machine-building in Russia since foreign companies have no interest in creating more competition.

\section{Conclusions}

Accumulated economic, social and environmental problems dictate the need for a new econo- 
my in Russia and worldwide. The final document of the Rio+20 Conference outlined the contours of a green economy, which is the basis for sustainable development. The transition to a green economy will happen differently in different countries, because it depends on specifics of the natural, human and physical capital of each country, its level of development and socio-economic priorities, as well as the environmental culture of each society. Each Russian district also will have its own way to new economic model.

The chief task of the Russian economy at the present time, as reflected in the main documents on the country's medium- and long-term development, is to move away from the raw-material model. This is also the central task in the concept of the green economy. In Russia modernization of the economy and transition to the green economy largely coincide. This "win-win" policy should be a guiding principle of Russia's socio-economic and environmental policy in the next $10-20$ years. In particular, the country needs to improve radically its energy efficiency since this will have a huge environmental impact.

Modernization and structural-technological changes could increase Russia's GDP by $2-3$ times at the country's present level of production and use of natural resources, by deploying the huge amounts of raw materials, which would be saved, in the domestic economy and for export. This would greatly improve the well-being, and the social and environmental quality of life of the Russian population. This is the main direction to the creation of a green economy in Russia and her regions. It requires investment in a new, resource-sparing structure of the economy and radical technology upgrade, greening the economy and reducing its environment intensity, thereby conserving natural capital and minimizing the cost of remedying negative environmental impacts now and in the future.

The effectiveness of state regulation of the extraction and use of resources and protection of the environment needs to be strengthened. Economic and legal instruments should be used to encourage and compel publicly owned and private companies to improve their resource efficiency through modernization and innovation, to prevent wastage of raw materials, and to adequately compensate for damage inflicted on society and the environment.

\section{Acknowledgement}

The research was supported by the grant of the Russian Foundation for Basic Research No. 14-06-00075

\section{References}

1. Budushcheye, kotorogo my khotim [The future we want]. (19 of June, 2012). Itogovyy dokument Konferentsii OON [The final document of the UN Conference]. Rio de Janeiro.

2. Declaration on Green Growth. (25 June 2009). OECD.

3. Green Growth: Overcoming the Crisis and Beyond. (2009). OECD.

4. Sustainable Development and Eco-innovation: Towards a Green Economy. (June 2009). OECD Policy Brief.

5. Promotion of Green Industry for Green Growth. (August 2009). UN ESCAP. Background Paper.

6. Navstrechu «zelyonoy» ekonomike: puti k ustoychivomu razvitiyu i iskoreneniyu bednosti - obobshchayushchiy doklad dlya predstaviteley vlastnykh struktur [Towards a green economy: pathways to sustainable development and poverty eradication]. (2011). UNEP.

7. Barbier, E. (2010). Green Stimulus, Green Recovery and Global Imbalances. World Economics, 11(2), 149-175;

8. Doklad o chelovecheskom razvitii. 2011 [Human development report 2011]. (2011). Ustoychivoye ravitie i ravenstvo vozmozhnostey: luchsheye budushcheye dlya vsekh [Sustainability and equity: a better future for all]. PROON [UNDP].

9. Gosudarstvennyy doklad «Ob okhrane okruzhayushchey sredy v Rossiyskoy Federatsii» [State report "On the state and environmental protection in Russian Federation"]. (2013). 463.

10. Doklad o razvitii chelovecheskogo potentsiala v RF 2003 [Report on Human Development in the Russian Federation 2003]. (2003). Edited by S. N. Bobylev Moscow: PROON [UNDP].

11. Sakayya, T. (1999). Stoimost sozdavayemaya znaniem, ili istoriya budushchego [Value created by knowledge, or the history of the future]. Novaya Postindustrialnaya volna na Zapade. Antologiya. [The new Post-industrial wave in the West (anthology)]. Moscow: Academia.

12. Bobylev. S. N. \& Zakharov, V. M. (2011). Modernizatsiya i ustoychivoye razvitie [Modernization and sustainable development]. Moscow: Economika Publ.

13. Ekonomika ekosistem i bioraznoobrazie dlya natsionalnyykh i mezhdunarodnykh lits, prnimayushchikh resheniya, UNEP [The economics of ecosystems and biodiversity for national and international policy maker]. (2009). UNEP, 429.

14. Bobylev, S. N., Zubarevich, N. V., Solovyova, S. V. \& Vlasov, Yu. S. (2011). Ustoychivoye razvitie: metodologiya i metodiki izmereniya [Sustainable development: methodology and measurement methods]. Moscow: Economika Publ.

15. Bobylev, S. N., Kudryavtseva, O. V. \& Solovyova, O. V. (2014). Indikatory ustoychivogo razvitiya dlya gorodov [Sustainable development indicators for cities]. Ekonomika regiona [Economy of Region], 3, 101-109.

16. Otsenka otsenok okruzhayushchey sredy Yevropy [Assessment of environmental estimates for Europe]. (2011). Yevropeyskoye agentstvo po okruzhayushchey srede [European environment Agency]. Copenhagen. 
17. Dekapling ispolzovaniya prirodnykh resursov i vozdeystviya na okruzhayushchuyu sredu ekonomicheskogo rosta [Decoupling natural resource use and environmental impacts from economic growth]. Doklad rabochey gruppy po dekaplingu IRP [A report of the working group on decoupling to the international resource panel]. (2011). UNEP, 154.

18. Doklad o chelovecheskom razvitii v Rossiyskoy Federatsii, 2013 [Report on human development in the Russian Federation, 2003]. (2014). Edited by S. N. Bobylev. Moscow: UNDP, 204.

19. Putin, V. V. (January, 30, 2012). O nashikh ekonomicheskikh zadachakh [Our tasks in the economy]. Vedomosti.

\section{Information about the authors:}

Bobylev Sergey Nikolayevich (Moscow, Russia) - Doctor of Economics, Professor, Department of Economics, Lomonosov Moscow State University (MSU, Faculty of Economics, Russia, 119991, Moscow, GSP-1, 1-46 Leninskiye Gory; e-mail: snbobylev@ yandex.ru).

Kudryavtseva Olga Vladimirovna (Moscow, Russia) - Doctor of Economics, Professor, Department of Economics, Lomonosov Moscow State University (MSU, Faculty of Economics, Russia, 119991, Moscow, GSP-1, 1-46 Leninskiye Gory; e-mail: olgakud@mail.ru).

Yakovleva Yekaterina Yuryevna (Moscow, Russia) - PhD Student, Department of Economics, Lomonosov Moscow State University (MSU, Faculty of Economics, Russia, 119991, Moscow, GSP-1, 1-46 Leninskiye Gory; e-mail: e.u.yakovleva@gmail. com). 